\title{
Syzygium aromaticum Essential Oil to the Control of Tenuipalpus heveae
}

\author{
Thalia Mayara Pereira de Melo ${ }^{1}$, Eliamara Marques da Silva ${ }^{1}$, Abimael Gomes da Silva $^{2}$, \\ Gustavo Haralampidou da Costa Vieira ${ }^{1} \&$ Beatriz Garcia Lopes ${ }^{2}$ \\ ${ }^{1}$ State University of Mato Grosso do Sul, Municipality of Cassilândia, MS, Brazil \\ 2 Paulista State University "Júlio de Mesquita Filho”, Municipality of Ilha Solteira, SP, Brazil \\ Correspondence: Gustavo Haralampidou da Costa Vieira, State University of Mato Grosso do Sul, Rod. MS 306, \\ km 6,4, Municipality of Cassilândia, MS, Brazil. E-mail: gcv@uems.br
}

Received: February 28, $2019 \quad$ Accepted: April 2, $2019 \quad$ Online Published: June 15, 2019

doi:10.5539/jas.v11n8p295 URL: https://doi.org/10.5539/jas.v11n8p295

The research is financed by PIBIC-PROPP-UEMS.

\begin{abstract}
The objective was to determine the effect of essential oils on the mortality and repellency of the Tenuipalpus heveae Baker mite (Acari, Tenuipalpidae). Leaf discs of rubber trees were deposited in Petri dishes containing a moistened cotton layer. Posteriorly, the essential oils were diluted to formulate solutions, which were sprayed onto the discs. The experimental design was completely randomized, in a $3 \times 4$ factorial design: neem, cedar and clove oils at doses $0,10 \mu \mathrm{L}, 50 \mu \mathrm{L}$ and $100 \mu \mathrm{L}$, with five replicates, with ten adult females being considered per replicate. The exposure to the effect of essential oil was evaluated after 24, 48, 72 and 96 hours for the number of females dead and females in the cotton. The data were submitted to analysis of variance, the values were transformed into $(x+0.5)^{1 / 2}$, and the means were grouped by the Scott-Knot test at $5 \%$ probability for the treatments, the doses were submitted to regression analysis. From the 48 hours of evaluation, clove oil showed greater potential for adult mite mortality, being 1.38 in 48 hours, 1.40 in 72 hours and 1.50 in 96 hours. The dose of $100 \mu \mathrm{L}$ presented a greater potential for the neem and clove oils. The clove essential oil has potential in the control of Tenuipalpus heveae.
\end{abstract}

Keywords: rubber tree, phytophagous mite, alternative control

\section{Introduction}

The rubber tree [Hevea brasiliensis (Willd. ex Adr. De Juss.) Müell. Arg., Euphorbiaceae] is native to the Amazon Region. Its cultivation is of great economic importance because it is the main source of natural rubber by the extraction of latex (Liu et al., 2015).

The high latex yield is guaranteed by the environmental management associated with genetic improvement. Currently, pest and disease control are mainly done by zoning, use of resistant clones and by chemical control (Guyot \& Le Guen, 2018, Vieira, Celoto, Scaloppi Junior, \& Agustini, 2017). The main pests occurring in regions with commercial rubber plantations in Brazil are phytophagous mites, especially Calacarus heveae Feres (Acari: Eriophyidae) and Tenuipalpus heveae Baker (Acari: Tenuipalpidae) (Juliatti, Fonseca, Carneiro, Juliatti, \& Santos, 2018).

In $T$. heveae samples collected from rubber tree leaves, the frequency of females corresponds to almost all samples, the development period from the egg to the adult can be influenced by environmental conditions and the different clones of $H$. brasiliensis in which they are associated (Castro, Ramos, Feres, Ochoa, \& Bauchan, 2017). This species presents fast capacity to double its population causing great damage to the plant (Feres Del'arco, \& Daud, 2010): leaf darkening, culminating with defoliation, are symptoms of infestation that result in a decrease of latex yield (Martins et al., 2012). The population dynamics and seasonality of this species are associated with the period of greatest rainfall and relative humidity (Vieira et al., 2017).

The main control method used against mites is the use of synthetic acaricides, but their excessive and inadequate use can cause several problems, among them the contamination of the environment and intoxications in farmers 
and consumers, these products also present low selectivity to natural enemies, which results in a decrease of the richness and diversity of local species (Moraes \& Flechtmann, 2008). Thus, other forms of disease and pest management should be considered (Alvarenga \& Carmo, 2014, Yessinou et al., 2016) such as the use of biological control or less toxic substances, such as extracts and essential oils of vegetable origin (Halfeld-Vieira, Marinho-Prado, Nechet, Morandi, \& Bettiol, 2016).

Essential oils are defined according to the International Standart Organization (ISO) as products originating from vegetable parts after the water vapor drag process. The compounds found in each essential oil vary according to the species and structure from which it was extracted, among its main components are simple alcohols, aldehydes, ketones, phenols, esters and organic acids (Santurio et al., 2007). The use of essential oil and its effect on pest control is of agricultural interest and is reported in several studies (Barbosa, Dias, Guerra, \& Vieira, 2018; Jayakumar, Arivoli, Raveen, \& Tennyson, 2017; Lucca, Nóbrega, Alves, Cruz-Silva, \& Pacheco, 2015).

Vegetables such as neem, cedar and clove allow the extraction of essential oils studied for the control of pests and diseases in agricultural systems. The neem (Azadirachta indica A. Juss) and the cedar (Cedrela odorata L.) are trees belonging to the family Meliaceae (Neves, Oliveira, \& Mohn, 2003). They have as main metabolic secondary to azadirachtin, a substance with high insecticidal and acaricidal action and very low toxicity to man (Mansour, Ascher, \& Abo-Moch, 1997). The clove, Syzygium aromaticum (L.) Merrill and Perry (Myrtaceae), is distinguished by the essential oil with insecticidal potential for the control of pests because in its chemical composition there is the compound eugenol (Jairoce et al., 2016; Hong, Perumalsamy, Jang, Na, \& Ahn, 2018).

Studies with essential oils are basic to developing products to control pest infestations. These have advantages because of their low toxicity in mammals and because they cause a much lower environmental impact when compared to conventional products (Jia, He, Wang, Dai, \& Zhu 2018; Pavela, 2016). Given these assumptions, this work aimed to determine the effect of different essential oils on Tenuipalpus heveae mite mortality and repellency.

\section{Material and Methods}

The study was developed at the Laboratory of Entomology of the State University of Mato Grosso do Sul, Cassilandia-MS (19 $06^{\prime} 48^{\prime \prime} \mathrm{S}$ and $\left.51^{\circ} 44^{\prime} 03^{\prime \prime} \mathrm{W}\right)$.

The sensitivity test of mites to essential oils was conducted according to the methodology used by Tabet (2011), with changes in the mode of application of essential oil solutions. The mites were obtained from a field of the rubber tree, RRIM 600 clone, of approximately eight years of implantation, located at Experimental Farm of the State University of Mato Grosso do Sul, Cassilandia-MS.

Leaf discs $5 \mathrm{~cm}$ in diameter were deposited in $9 \mathrm{~cm}$ diameter Petri dishes containing a cotton layer moistened with distilled water. With a stylet the excess of mites from the leaf discs was removed, leaving only the number of individuals to be evaluated.

With a graduated micropipette, the essential oils were dosed and then diluted at the concentrations of $0,10,50$ and $100 \mu \mathrm{L} \mathrm{L}^{-1}$. To breakage the water tensions a drop of $\operatorname{Twin}^{\circledR}$ was used in each mixing. The essential oils were sprayed onto the leaf discs with a hand sprayer at a dose of $2 \mathrm{ml}$. The plates were kept in an air-conditioned room, at a temperature of $25.0 \pm 2.0^{\circ} \mathrm{C}$, relative humidity of $65.0 \pm 10.0 \%$ and $14 \mathrm{~h}$ of photophase.

Evaluations were performed after 24, 48, 72 and 96 hours, recording the number of dead females in the disk and the number of dead females in the wet cotton. This mortality in cotton is indicative of the effect of product repellency.

For the calculation of corrected mortality percentages (Mc\%), the Abbott equation was used (Nakano, Silveira Neto, \& Zucchi, 1981) modified by Tabet (2011):

$$
\mathrm{Mc} \%=\frac{\mathrm{T}-\mathrm{I}}{\mathrm{T}} \times 100
$$

where, $\mathrm{T}=$ number of live females + females found in the moistened cotton, in the control treatment (spraying with deionized water), $\mathrm{I}=$ number of live females + females found in the cotton moistened in the treatment tested.

This calculation considers that females found in the moist cotton could be alive if they had not fallen into the water barrier.

The percentages of repellency (Rc\%) were calculated by the equation of Abbott (Nakano et al., 1981) modified by Tabet (2011): 


$$
\mathrm{Rc} \%=\frac{\mathrm{T}-\mathrm{I}}{\mathrm{T}} \times 100
$$

where, $\mathrm{T}=$ number of live females + dead females on the disc, in the control treatment (spraying with deionized water), $\mathrm{I}=$ number of live females + females dead on the disc in the treatment tested. This calculation considers that the treatments repelled the females found in moist cotton.

The experimental design was completely randomized in a $3 \times 4$ factorial design (neem, cedar and clove oils) at doses of $(0,10 \mu \mathrm{L}, 50 \mu \mathrm{L}$, and $100 \mu \mathrm{L})$, with five replicates, considering ten mites by replication. Data were submitted to analysis of variance by statistical software Sisvar (Ferreira, 2011). For the analysis, the values of the number of dead females on the disc and the number of dead females in the wet cotton were transformed into (x + $0.5)^{1 / 2}$, and the means were grouped by the Scott-Knot test at $5 \%$ of probability, for treatments and regression for doses.

\section{Results and Discussion}

There was no interaction between the factor oils and doses in adult mortality; in this way, the influence of the treatments was analyzed independently.

About the evaluations in the periods of 24, 48 and 96 hours (Table 1), the different essential oils caused mortality in the adult females of $T$. Heveae. Higher values of mortality in the adult females of $T$. Heveae. were observed with the use of clove essential oil when compared to the two other essential oils in all evaluated periods. The other two treatments showed similar results among themselves. The analysis of adult females in cotton (AFC) presented results that were statistically similar in all evaluated periods.

Table 1. Number of dead adult females (DAF) and adult females in the cotton (AFC) of Tenuipalpus heveae sprayed with different oils, in the periods of 24, 48 and 96 hours. Cassilandia, 2017

\begin{tabular}{|c|c|c|c|c|c|c|}
\hline Treatment & DAF & $\mathrm{AFC}$ & DAF & $\mathrm{AFC}$ & DAF & $\mathrm{AFC}$ \\
\hline & \multicolumn{2}{|c|}{------------ 24 h ------------ } & \multicolumn{2}{|c|}{------------- 48 h ------------ } & \multicolumn{2}{|c|}{------------ 96 h ------------ } \\
\hline Cedar & $1.19 \mathrm{~b}$ & 1.04 & $1.09 \mathrm{~b}$ & 1.08 & $1.22 \mathrm{~b}$ & 1.06 \\
\hline Clove & $1.38 \mathrm{a}$ & 1.04 & $1.40 \mathrm{a}$ & 1.08 & $1.50 \mathrm{a}$ & 1.01 \\
\hline Neem & $1.15 b$ & 1.06 & $1.17 \mathrm{~b}$ & 1.06 & $1.10 \mathrm{~b}$ & 1.06 \\
\hline Coefficient of variation $(\%)$ & 20.16 & 14.56 & 19.56 & 15.72 & 19.56 & 15.72 \\
\hline
\end{tabular}

Note. Means followed by the same letter belong to the same group by the Scott-Knot test $(\mathrm{P}=0.05)$. The data were transformed by $(\mathrm{x}+0.5)^{1 / 2}$.

The statistical relationship between clove oil doses and $T$. heveae mortality were tested to evaluate the ratio of clove oil (dose) concentrations and the exposure period of the mite to this agent. From the regression tests considered up to the fourth order, it was not possible to find a regression model that demonstrates the behavior of mite mortality by the effect of clove oil concentrations for 24 hours of exposure significantly. The following criteria were used to consider the regressions: satisfactory $\mathrm{R}^{2}(>70)$, the $\mathrm{p}$-value of the regression presented significance $(<0.05)$, and a p-value of deviations from the regression analysis used compared to the next order presented $p$-value not significant ( $p$-value $>0.05$ ). Thus, in the Table 2 are presented the statistical characteristics of the regression model, as well as the means of the dependent variables and behavior of the effect of the doses used on the adult mite mortality for evaluations of 48, 72 and 96 hours of application. The effect of the four doses of clove oil $\left(0.10,50\right.$ and $\left.100 \mu \mathrm{L} \mathrm{L}^{-1}\right)$ was analyzed by the use of the regression test up to the fourth order. According to $\mathrm{R}^{2}$, it was observed that more than $80 \%$ of the data are adjusted to the regression models used, and the linear model is adequate for the mortality of the mites at different periods of exposure to the oil doses (Figure 1). 
Table 2. Means of the effect of clove oil doses on the mortality of $T$. heveae due to the time of exposure to these doses

\begin{tabular}{llll}
\hline \multirow{2}{*}{ Concentration $\left(\mu \mathrm{L} \mathrm{L}^{-1}\right)$} & \multicolumn{3}{c}{ Time of exposure } \\
\cline { 2 - 4 } & $48 \mathrm{~h}$ & $72 \mathrm{~h}$ & $96 \mathrm{~h}$ \\
\hline 0 & 0.707 & 0.707 & 0.707 \\
10 & 1.088 & 1.088 & 1.017 \\
50 & 1.439 & 1.496 & 1.264 \\
100 & 1.568 & 1.721 & 2.008 \\
\hline Equation P-value & $0^{* *}$ & $0^{* *}$ & $0^{* *}$ \\
Deviation P-value & $0.182^{\mathrm{ns}}$ & $0.336^{\mathrm{ns}}$ & $0.188^{\mathrm{ns}}$ \\
Average & 1.20 & 1.25 & 1.25 \\
Coefficient of variation $(\%)$ & 20.12 & 25.00 & 21.71 \\
\hline
\end{tabular}

In the evaluation of the exposure of the mite to the oil (Figure 1), it was observed that, in general, the increase of the doses resulted in an increase in the mortality of the sample of adult mite females in the three evaluated periods and, therefore, the higher mortality was observed in mites that were exposed to the dose of $100 \mu \mathrm{L} \mathrm{L}^{-1}$. According to Andrade and Nascimento (2012) the control of Varroa destructor (Acari: Varroidae) mite showed higher mortalities in the concentrations of $200 \mu \mathrm{L} \mathrm{L}^{-1}$ of clove oil causing $87.5 \%$ mortality of $V$. destructor mite while at the dose of 10 and $50 \mu \mathrm{L} \mathrm{L}^{-1}$ of this oil resulted in $75 \%$ mortality of the mite.

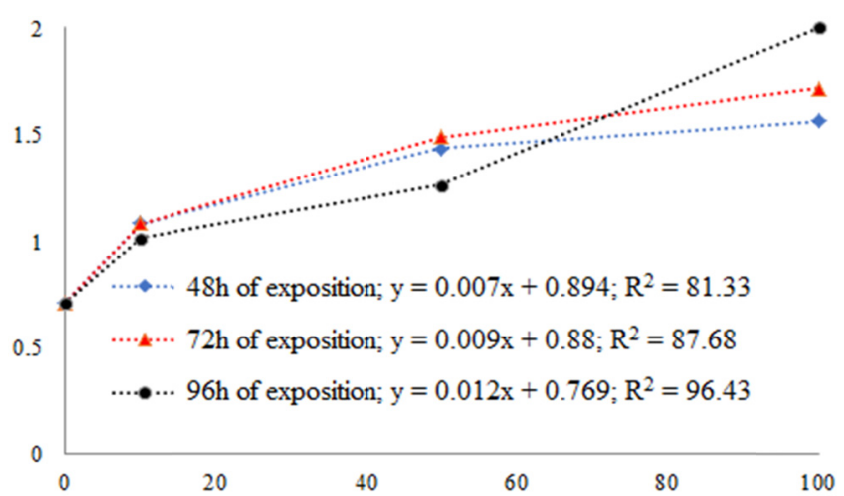

Figure 1. Mortality of adult females of $T$. heveae (y-axis) after 48, 72 and 96 hours exposure to different doses of clove essential oil ( $\mathrm{x}$-axis)

About the percentage of corrected mortality (Table 3), it can be observed that in 24 hours, the neem oil in the dose of $100 \mu \mathrm{L} \mathrm{L}^{-1}$ was the one that obtained a greater percentage of mortality $(10,42)$ and corrected repellency $(24,49)$. In 48 hours, clove oil was the one that affected the mortality of females of $T$. heveae, causing mortality of 14 and $18 \%$ in doses of 50 and $100 \mu \mathrm{L} \mathrm{L}^{-1}$. It is observed that the cedar essential oil obtained negative values on the mortality of the mite, independent of the dose used. At 72 hours after the spraying of oils, showed that the highest corrected mortalities values in neem oil, $10 \%$ at doses of $100 \mu \mathrm{L} \mathrm{L}^{-1}$, and for clove essential oil $14 \%$ and $24 \%$, respectively, at doses of 50 and $100 \mu \mathrm{L} \mathrm{L}^{-1}$. During this period, no evaluated oil showed a repellent effect.

It was reported by Schlesener, Duarte, Guerrero, Cunha and Nava (2013), high corrected mortality caused by the neem oil spraying on Tetranychus urticae (Acari: Tetranychidae). This same effect was not observed in this study. In the study of the Varroa destructor mite, a parasite of Apis melifera L. (Hymenoptera: Apidae), it was verified that the oil of clove has an acaricidal effect on this species without affecting the bees. Different doses of clove oil presented relevant results on the mortality of mites: a dose of $10 \mu \mathrm{L}$ and $50 \mu \mathrm{L}$ resulted in a mortality rate of $75 \%$, in the dose of $200 \mu \mathrm{L}$, the mortality values were $87.5 \%$ for clove oil.

The highest corrected mortality value (33\%) was observed in the period of 96 hours with clove oil use at the dose of $100 \mu \mathrm{L} \mathrm{L}^{-1}$ (Table 3 Although this value is considered low, it is still higher than what was reported by Tabet (2011) in the mortality of T. urticae females under clove essential oil spraying. 
Table 3. Corrected mortality corrected percentages (Mc) and percentage of repellency (Rc) after spraying with plant extracts in samples of T. heveae

\begin{tabular}{|c|c|c|c|c|c|c|c|c|c|c|}
\hline \multirow{2}{*}{ Treatments } & & & \multicolumn{2}{|c|}{24 hours } & \multicolumn{2}{|c|}{48 hours } & \multicolumn{2}{|c|}{72 hours } & \multicolumn{2}{|c|}{96 hours } \\
\hline & & & $\operatorname{Mc}(\%)$ & $\operatorname{Rc}(\%)$ & $\operatorname{Mc}(\%)$ & $\operatorname{Rc}(\%)$ & $\operatorname{Mc}(\%)$ & $\operatorname{Rc}(\%)$ & $\operatorname{Mc}(\%)$ & $\operatorname{Rc}(\%)$ \\
\hline \multirow{9}{*}{ Dose $\left(\mu \mathrm{L} \mathrm{L}^{-1}\right)$} & & 10 & 0 & 2.04 & 0 & 0 & 2 & -2.04 & 2.17 & 2 \\
\hline & Neem & 50 & -2.08 & 0 & 6 & 2 & 6 & -2.04 & 2.17 & 2 \\
\hline & & 100 & 10.42 & 24.49 & 10 & -4 & 10 & 2.04 & 4.35 & 2 \\
\hline & & 10 & -4.26 & 0 & -4.26 & 0 & -2.04 & -2.08 & 2 & 2 \\
\hline & Cedar & 50 & -2.13 & 4 & -2.13 & 2 & 0 & -2.08 & 2 & 0 \\
\hline & & 100 & 0 & 4 & 2.13 & 2 & 4.08 & -4.16 & 6 & 4 \\
\hline & & 10 & 4.08 & 2 & 8 & 0 & 6 & 0 & 2.08 & 0 \\
\hline & Clove & 50 & 0 & 0 & 14 & 2 & 14 & 0 & 8.33 & 0 \\
\hline & & 100 & 10.2 & 6 & 18 & 2 & 24 & 0 & 33.33 & 0 \\
\hline
\end{tabular}

The presence of Eugenol is responsible for action in the control of agricultural pests and according to Kheradmand, Beynaghi, Asgari, and Garjan (2015), this plant can present almost $80 \%$ of this substance. In a study with Rhipicephalus (Boophilus) microplus (Acari: Ixodidae), it was observed that the use of clove oil at the dose of $100 \mathrm{mg} \mathrm{mL}^{-1}$ presented $100 \%$ efficiency, as well as the same dose of synthetic Eugenol, in adult mortality of ectoparasite (Ferreira et al., 2018) that is usually controlled with the use of commercial acaricides (Yessinou et al., 2016). The rapid action of clove oil on mites may indicate that its mechanism of action is neurotoxic (Isman, 2006). However, Moraes and Flechtmann (2008) report that essential oils penetrate the body of the mites by breathing that is, it penetrates the body of these arthropods through the cuticle, the only respiratory surface of these organisms.

The results of this work demonstrated that the mortality of adult mites was proportional to the dose of clove oil used. Similar results for adult mortality, in addition to the repellent effect, were reported for the control of the mite Tetranychus urticae (Kheradmand et al., 2015). In addition to promising acaricide, clove oil presents an insecticidal action due to the presence of eugenyl acetate, methyl salicylate, eugenol, and eugenyl acetate. These are detrimental to the development of larvae of Bradysia procera, Diptera: Sciaridae (Hong et al., 2018).

According to the results demonstrated by the Mc calculation (Table 3), it is recommended new studies with larger doses to observe if the performance of the clove essential oil continues proportional to the increase of its dose. The results indicate that clove oil has the potential for use as a component of products indicated to the control of the studied mite.

\section{Conclusions}

The results of the mortality of adult females of Tenuipalpus heveae treated with the clove essential oil showed that this oil can be an alternative in the phytosanitary management in Hevea brasiliensis affected by this phytophagous mite.

\section{References}

Alvarenga, A. P., \& Carmo, C. A. F. S. C. (2014). Seringueira (2nd ed., Cap. 12, pp. 595-632). Viçosa: EPAMIG Zona da Mata.

Barbosa, M. S., Dias, B. B., Guerra, M. S., \& Vieira, G. H. C. (2018). Applying plant oils to control fall armyworm (Spodoptera frugiperda) in corn. AJCS, 12(4), 557-562. https://doi.org/10.21475/ajcs.18.12. 04.pne822

Castro, E. B., Ramos, F. A. M., Feres, R. J. F., Ochoa, R., \& Bauchan, G. R. (2017). Redescription of Tenuipalpus heveae Baker (Acari: Tenuipalpidae) and description of a new species from rubber trees in Brazil. Acarologia, 57(2), 421-458. https://doi.org/10.1051/acarologia/20174166

Feres, R. J. F., Del'arco, M., \& Daud, R. D. (2010). Biological cycle of Tenuipalpus heveae Baker (Acari, Tenuipalpidae) on leaflets of three rubber tree clones. Revista Brasileira de Entomologia, 54(2), 298-303. https://doi.org/10.1590/S0085-56262010000200013

Ferreira, D. F. (2011). Sisvar: A computer statistical analysis system. Ciências e Agrotecnologia, 35(6), 1039-1042. https://doi.org/10.1590/S1413-70542011000600001 
Ferreira, F. M., Delmonte, C. C., Novato, T. L. P., Monteiro, C. M. O., Daemon, E., Vilela, F. M. P., \& Amaral, M. P. H. (2018). Acaricidal activity of essential oil of Syzygium aromaticum, hydrolate and eugenol formulated or free on larvae and engorged females of Rhipicephalus microplus. Medical and Veterinary Entomology, 32(1) 41-47. https://doi.org/0.1111/mve.12259

Guyot, J., \& Le Guen, V. (2018). A Review of a Century of Studies on South American Leaf Blight of the Rubber Tree. Plant Disease, 102(6) 1052-1065. https://doi.org/10.1094/PDIS-04-17-0592-FE

Halfeld-Vieira, B. A., Marinho-Prado, J. S., Nechet, K. L., Morandi, M. A. B., \& Bettiol, W. (2016). Defensivos Agrícolas Naturais: Uso e perspectivas. Brasilia: EMBRAPA.

Hong, T., Perumalsamy, H., Jang, K., Na, E., \& Ahn, Y. (2018). Ovicidal and larvicidal activity and possible mode of action of phenylpropanoids and ketone identified in Syzygium aromaticum bud against Bradysia procera. Pesticide Biochemistry and Physiology, 145, 29-38. https://doi.org/10.1016/j.pestbp.2018.01.003

Isman, M. B. (2006). Botanical insecticides, deterrents, and repellents in modern agriculture and an increasingly regulated world. Annual Review Entomology, 51(1), 45-66. https://doi.org/10.1146/annurev.ento.51.110104. 151146

Jairoce, C. F., Teixeira, C. M., Nunes, C. F. P., Nunes, A. M., Pereira, C. M. P., \& Garcia, F. R. M. (2016). Insecticide activity of clove essential oil on bean weevil and maize weevil. Revista Brasileira de Engenharia Agrícola e Ambiental, 20(1), 72-77. https://doi.org/10.1590/1807-1929/agriambi.v20n1p72-77

Jayakumar, M., Arivoli, S., Raveen, R., \& Tennyson, S. (2017). Repellent activity and fumigant toxicity of a few plant oils against the adult rice weevil Sitophilus oryzae Linnaeus 1763 (Coleoptera: Curculionidae). Journal of Entomology and Zoology Studies, 5(2), 324-335.

Jia, M., He, Q., Wang, W., Dai, J., \& Zhu, L. (2018). Chemical composition and acaricidal activity of Arisaema anurans essential oil and its major constituents against Rhipicephalus microplus (Acari: Ixodidae). Veterinary Parasitology, 216, 59-66. https://doi.org/10.1016/j.vetpar.2018.08.006

Juliatti, F. C., Fonseca, H. I., Carneiro, M. A. B., Juliatti, B. C. M., \& Santos, L. N. (2018). Association of "green spot" and defoliation to Tenuipalpus Heveae incidence and chemical control screening of Hevea Brasiliensis diseases. Bioscience Journal, 34(5), 1274-1280. https://doi.org/10.14393/BJ-v34n5a201842670

Kheradmand, K., Beynaghi, S., Asgari, S., \& Garjan, A. S. Toxicity and Repellency Effects of Three Plant Essential Oils Against Two-spotted Spider Mite, Tetranychus urticae (Acari: Tetranychidae). Journal of Agricultural Science and Technology, 17, 1223-1232.

Liu, S., Lan, J., Zhou, B., Qin, Y., Zhou, Y., Xiao, X., ... Tang, C. (2015). HbNIN2, a cytosolic alkaline/neutral-invertase, is responsible for sucrose catabolism in rubber-producing laticifers of Hevea brasiliensis (para rubber tree). New Phytologist, 206(2), 709-725. https://doi.org/10.1111/nph.13257

Lucca, P. S. R., Nóbrega, L. H. P., Alves, L. F. A., Cruz-Silva C. T. A., \& Pacheco, F. P. (2015). The insecticidal potential of Foeniculum vulgare Mill., Pimpinella anisum L. and Caryophillus aromaticus L. to control aphid on kale plants. Revista Brasileira de Plantas Medicinais, 17(4), 585-591. https://doi.org/10.1590/ 1983-084X/14_036

Mansour, F. A., Ascher, K. R. S., \& Abo-Moch, F. (1997). Effects of Neemgard on phytophagous and predacious mites and on spiders. Phytoparasitica, 25, 333-336. https://doi.org/10.1007/BF02981097

Martins, G. L. M., Vieira, M. R., Barbosa, J. C., Dini, T. A., Manzano, A. M., Alves, B. M. S., \& Silva, R. M. (2012). Distribuição espacial de Calacarus heveae Feres na cultura da seringueira em Marinópolis-São Paulo. Revista Árvore, 36(2), 211-217.

Moraes, G. J., \& Flechtmann, C. H. W. (2008). Manual de Acarologia: Acarologia básica e ácaros de plantas cultivadas no Brasil (p. 308). Ribeirão Preto: Holos.

Nakano, O., Silveira Neto, S., \& Zucchi, R. A. (1981). Entomologia Econômica (p. 314). Piracicaba: Livro ceres.

Neves, B. P., Oliveira, I. P., \& Mohn, J. C. (2003). Cultivo e Utilização do Nim Indiano (p. 12). Santo Antônio de Goiás: EMBRAPA (Circular Técnica, 62).

Pavela, R. (2016). History, Presence and Perspective of Using Plant Extracts as Commercial Botanical Insecticides and Farm Products for Protection against Insects-A Review. Plant Protect Science, 52(4), 229-241. https://doi.org/10.17221/31/2016-PPS 
Santurio, J. M. Santurio, D. F., Pozzatti, P., Moraes, C., Franchin, P. R., Alves, S. H. (2007). Atividade antimicrobiana dos óleos essenciais de orégano, tomilho e canela frente a sorovares de Salmonella entérica de origem avícola. Ciência Rural, 37(3), 803-808. https://doi.org/10.1590/S0103-84782007000300031

Schlesener, D. C. H., Duarte, A. F., Guerrero, M. F. C., Cunha, U. S., \& Nava, D. E. (2013). Efeitos do nim sobre Tetranychus urticae Koch (Acari: Tetranychidae) e os predadores Phytoseiulus macropilis (Banks) e Neoseiulus californicus (Mcgregor) (Acari: Phytoseiidae). Revista Brasileira de Fruticultura, 35(1), 059-066. https://doi.org/10.1590/S0100-29452013000100008

Tabet, V. G. (2011). Extratos vegetais e produtos naturais com potencial de uso no controle de Tetranychus urticae Koch (Acari: Tetranychidae) na cultura da videira (Dissertação de mestrado, Universidade Estadual de São Paulo-Ilha solteira, SP, Brazil).

Vieira, G. H. C., Andrade, W. P., \& Nascimento, D. M. (2012). Uso de óleos essenciais no controle do ácaro Varroa destructor em Apis mellifera. Pesquisa Agropecuária Tropical, 42(3), 317-322. https://doi.org/ $10.1590 / \mathrm{S} 1983-40632012000300014$

Vieira, M. R., Celoto, F. J., Scaloppi Junior, E. J., \& Agustini, J. A. (2017). Mites resistance of rubber tree clones in the northwestern São Paulo State conditions. Bragantia, 76(1), 102-107. https://doi.org/10.1590/ $1678-4499.609$

Yessinou, R. E., Akpo, Y., Adoligbe, C., Adoligbe, C., Adinci, J., Assogba, M. N., Koutinhouin, B., Karim, I. Y. A., \& Farougou, S. (2016). Resistance of tick Rhipicephalus microplus to acaricides and control strategies. Journal of Entomology and Zoology Studies, 4(6), 408-414. https://doi.org/10.22271/j.ento

\section{Copyrights}

Copyright for this article is retained by the author(s), with first publication rights granted to the journal.

This is an open-access article distributed under the terms and conditions of the Creative Commons Attribution license (http://creativecommons.org/licenses/by/4.0/). 